\title{
NOVEMBER 1977
}

SEVENTEENTH YEAR - No. 200
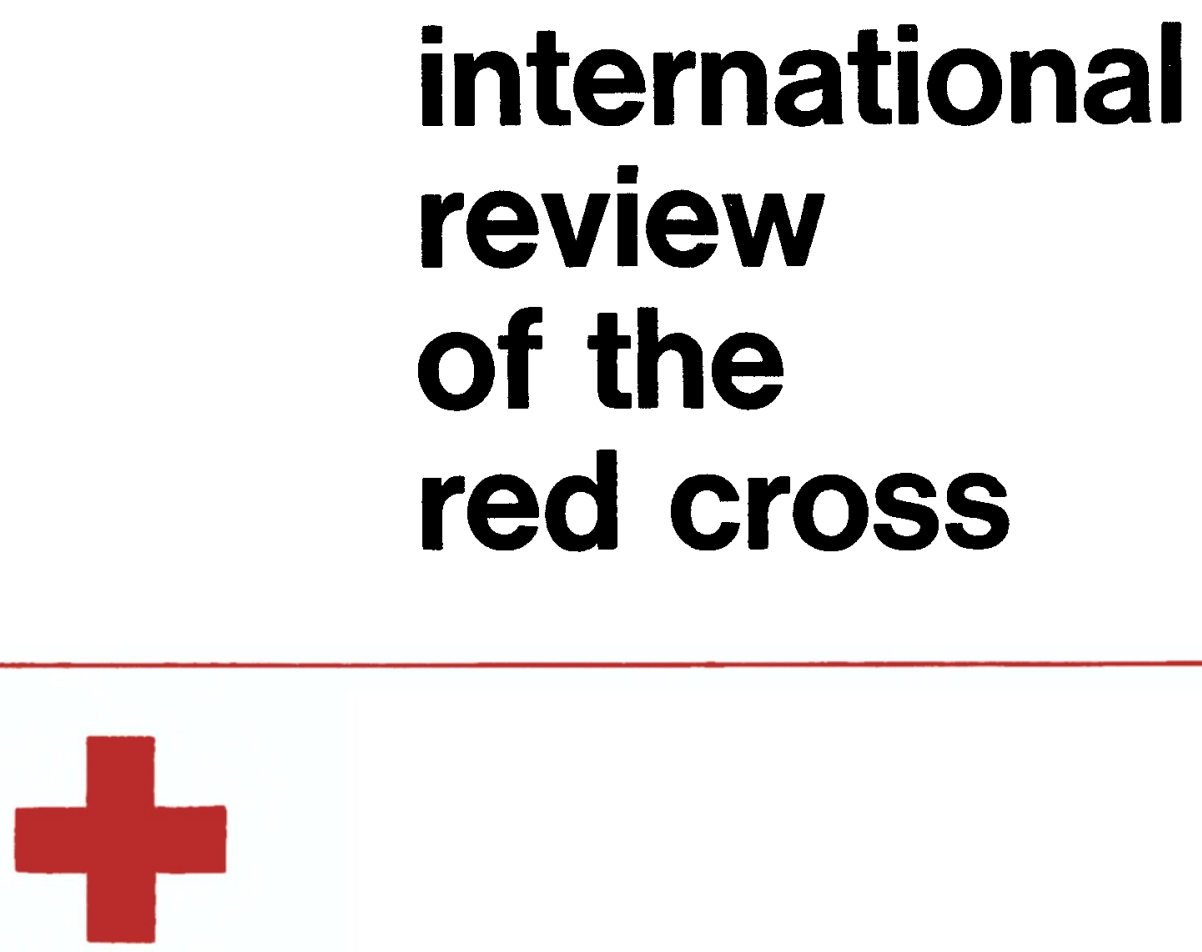

INTER ARMA CARITAS

GENEVA

INTERNATIONAL COMMITTEE OF THE RED CROSS

FOUNDED IN 1863 


\section{INTERNATIONAL COMMITTEE OF THE RED CROSS}

Mr. ALEXANDRE HAY, Lawyer, former Director-General of the Swiss National Bank, President (member since 1975)

Mr. JEAN PICTET, Doctor of Laws, Chairman of the Legal Commission, Director of the Henry Dunant Institute, Associate Professor at the University of Geneva, Vice-President (1967)

Mr. HARALD HUBER, Doctor of Laws, Federal Court Judge, Vice-President (1969)

Mrs. DENISE BINDSCHEDLER-ROBERT, Doctor of Laws, Professor at the Graduate Institute of International Studies, Geneva, Judge at the European Court of Human Rights (1967)

Mr. MARCEL A. NAVILLE, Master of Arts, ICRC President from 1969 to 1973 (1967)

Mr. JACQUES F. DE ROUGEMONT, Doctor of Medicine (1967)

Mr. ROGER GALLOPIN, Doctor of Laws, former ICRC Director-General and former President of the Executive Council (1967)

Mr. VICTOR H. UMBRICHT, Doctor of Laws, Managing Director (1970)

Mr. GILBERT ETIENNE, Professor at the Graduate Institute of International Studies and at the Institut d'études du développement, Geneva (1973)

Mr. ULRICH MIDDENDORP, Doctor of Medicine, head of surgical department of the Cantonal Hospital, Winterthur (1973)

Mrs. MARION BOVÉE-ROTHENBACH, Master of Social Work (University of Michigan), Reader at the Ecole des Sciences sociales et politiques of the University of Lausanne (1973)

Mr. HANS PETER TSCHUDI, Doctor of Laws, former Swiss Federal Councillor (1973)

Mr. HENRY HUGUENIN, Bank Manager (1974)

Mr. JAKOB BURCKHARDT, Doctor of Laws, Minister Plenipotentiary, Chairman of the Council of Federal Polytechnic Schools (1975)

Mr. THOMAS FLEINER, Master of Laws, Professor at the University of Fribourg (1975)

Mr. HERBERT LÜTHY, Doctor of Philosophy, Professor of History at the University of Basle (1975)

Mr. RICHARD PESTALOZZI, Doctor of Laws, Special Assistant to the President (1977)

Honorary members: Miss LUCIE ODIER, Honorary Vice-President;

Messrs. HANS BACHMANN,

GUILLAUME BORDIER,

Mrs. MARGUERITE GAUTIER-VAN BERCHEM,

Messrs. ADOLPHE GRAEDEL, EDOUARD DE HALLER, ERIC MARTIN,

RODOLFO OLGIATI, MAX PETITPIERRE, PAUL RUEGGER,

DIETRICH SCHINDLER, FRÉDÉRIC SIORDET, ALFREDO VANNOTTI.

\section{EXECUTIVE COUNCIL}

Mr. ALEXANDRE HAY, President

Mr. VICTOR H. UMBRICHT, Vice-President

Mr. RICHARD PESTALOZZI

MrS. DENISE BINDSCHEDLER-ROBERT

Mr. THOMAS FLEINER

Mr. JEAN PICTET 


\section{CONTENTS}

\section{INTERNATIONAL REVIEW OF THE RED CROSS}

November - No. 200

Twenty-third International Conference of the Red

Cross

INTERNATIONAL COMMITTEE OF THE RED CROSS

IN THE RED CROSS WORLD

MISCELLANEOUS
Visits by ICRC President . . . . . . . . . . 476

Bahamas Red Cross at the ICRC . . . . . . . 476

Head of Polish Red Cross Training Service visits

ICRC . . . . . . . . . . . . . . . 477

League President at the ICRC . . . . . . . . 477

Resignation of a Committee member . . . . . 478

External activities:

Africa - Latin America - Asia - Europe -

Middle East . . . . . . . . . . . . . . . 479

Election of League President and Vice-Presidents 488

Nansen Medal for Malaysian Red Crescent . . 489

The Red Cross Teaching Guide . . . . . . . . 490

The ICRC's short-wave programmes . . . . . 493

The International Institute of Human Rights at

Strasbourg . . . . . . . . . . . . . . . . 496

Manila World Law Conference . . . . . . . . 497

Ratification of Protocol for prohibition of asphyxiating gases . . . . . . . . . . . . 498

World health target for basic human needs . . 499 
REVUE INTERNATIONALE

DE LA CROIX-ROUGE

REVISTA INTERNACIONAL

DE LA CRUZ ROJA

EXTRACTS FROM

THE REVIEW

GERMAN

INTERNATIONAL

REVIEW OF

THE RED CROSS
The French and Spanish editions, also issued every month, may be obtained at the same price.
Neue Rotkreuz-Gesellschaft - Der Präsident des IKRK beim Internationalen Suchdienst - Hundertjahrfeier des Finnischen Roten Kreuzes - Hundertjahrfeier des Griechischen Roten Kreuzes - Neuer Präsident und neue Vize-Präsidenten der Liga - Aussprache des Internationalen Roten Kreuzes iiber die «Grosse Studie ».

The International Review is published each month by the International Committee of the Red Cross

17, avenue de la Paix, 1211 Geneva, Switzerland Postal Cheque No. 12 - 1767 .

Annual subscription: Sw. Fr. 30.- (\$12.-)

Single copy Sw. Fr. 3.- (\$1.-)

EDTTOR: Michel TESTUZ

The International Committee of the Red Cross assumes responsibility only for material over its own signature. 